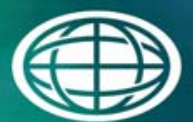

Savannah River

National Laboratory ${ }^{\mathrm{m}}$

OPERATED BY SAVANNAH RIVER NUCLEAR SOLUTIONS

\title{
The Impact of the MCU Life Extension Solvent on Sludge Batch 8 Projected Operating Windows
}

D.K. Peeler, T.B. Edwards, and M.E. Stone

August 2013

SRNL-STI-2013-00367, Revision 1 


\section{DISCLAIMER}

This work was prepared under an agreement with and funded by the U.S. Government. Neither the U.S. Government or its employees, nor any of its contractors, subcontractors or their employees, makes any express or implied:

1. warranty or assumes any legal liability for the accuracy, completeness, or for the use or results of such use of any information, product, or process disclosed; or

2. representation that such use or results of such use would not infringe privately owned rights; or

3. endorsement or recommendation of any specifically identified commercial product, process, or service.

Any views and opinions of authors expressed in this work do not necessarily state or reflect those of the United States Government, or its contractors, or subcontractors.

\section{Printed in the United States of America \\ Prepared for \\ U.S. Department of Energy}




\section{The Impact of the MCU Life Extension Solvent on Sludge Batch 8 Projected Operating Windows}

D.K. Peeler

T.B. Edwards

M.E. Stone

August 2013

Prepared for the U.S. Department of Energy under contract number DE-AC09-08SR22470. 


\section{REVIEWS AND APPROVALS}

\section{AUTHORS:}

D.K. Peeler, Process Technology Programs

Date

T.B. Edwards, Applied Computational Engineering and Statistics

Date

M.E. Stone, Process Technology Programs

Date

TECHNICAL REVIEW:

J.W. Amoroso, Process Technology Programs

Date

D.P. Lambert, Process Technology Programs

Date

APPROVAL:

D.R. Click, Manager

Date

Process Technology Programs

S.L. Marra, Manager

Date

Environmental \& Chemical Process Technology Research Programs

E.J. Freed, Manager

Date

SRR Engineering 


\section{PREFACE OR ACKNOWLEDGEMENTS}

The authors would like to thank David Newell, Jake Amoroso, and Dan Lambert for their technical guidance and insightful discussions. 


\section{EXECUTIVE SUMMARY}

As a part of the Actinide Removal Process (ARP)/Modular Caustic Side Solvent Extraction Unit (MCU) Life Extension Project, a next generation solvent (NGS) and a new strip acid will be deployed. The strip acid will be changed from dilute nitric acid to dilute boric acid $(0.01 \mathrm{M})$. Because of these changes, experimental testing or evaluations with the next generation solvent are required to determine the impact of these changes (if any) to Chemical Process Cell (CPC) activities, glass formulation strategies, and melter operations at the Defense Waste Processing Facility (DWPF).

The introduction of the dilute $(0.01 \mathrm{M})$ boric acid stream into the DWPF flowsheet has a potential impact on glass formulation and frit development efforts since $\mathrm{B}_{2} \mathrm{O}_{3}$ is a major oxide in frits developed for DWPF. Prior knowledge of this stream can be accounted for during frit development efforts but that was not the case for Sludge Batch 8 (SB8). Frit 803 has already been recommended and procured for SB8 processing; altering the frit to account for the incoming boron from the strip effluent (SE) is not an option for SB8. Therefore, the operational robustness of Frit 803 to the introduction of SE including its compositional tolerances (i.e., up to $0.0125 \mathrm{M}$ boric acid) is of interest and was the focus of this study. The primary question to be addressed in the current study was: What is the impact (if any) on the projected operating windows for the Frit 803 - SB8 flowsheet to additions of $\mathrm{B}_{2} \mathrm{O}_{3}$ from the SE in the Sludge Receipt and Adjustment Tank (SRAT)? More specifically, will Frit 803 be robust to the potential compositional changes occurring in the SRAT due to sludge variation, varying additions of ARP and/or the introduction of SE by providing access to waste loadings (WLs) of interest to DWPF?

The Measurement Acceptability Region (MAR) results indicate there is very little, if any, impact on the projected operating windows for the Frit 803 - SB8 system regardless of the presence or absence of ARP and $\mathrm{SE}$ (up to $2 \mathrm{wt} \% \mathrm{~B}_{2} \mathrm{O}_{3}$ contained in the SRAT and up to 2000 gallons of ARP). It should be noted that $0.95 \mathrm{wt} \% \mathrm{~B}_{2} \mathrm{O}_{3}$ is the nominal projected concentration in the SRAT based on a $0.0125 \mathrm{M}$ boric acid flowsheet with 70,000 liters of SE being added to the SRAT.

The impact on CPC processing of a $0.01 \mathrm{M}$ boric acid solution for elution of cesium during Modular Caustic Side Solvent Extraction Unit (MCU) processing has previously been evaluated by the Savannah River National Laboratory (SRNL). Increasing the acid strength to $0.0125 \mathrm{M}$ boric acid to account for variations in the boric acid strength has been reviewed versus the previous evaluation. The amount of acid from the boric acid represented approximately $5 \%$ of the total acid during the previous evaluation. An increase from 0.01 to $0.0125 \mathrm{M}$ boric acid represents a change of approximately $1.3 \%$ which is well within the error of the acid calculation. Therefore, no significant changes to CPC processing (hydrogen generation, metal solubilities, rheological properties, REDOX control, etc.) are expected from an increase in allowable boric acid concentration from $0.01 \mathrm{M}$ to $0.0125 \mathrm{M}$. 


\section{TABLE OF CONTENTS}

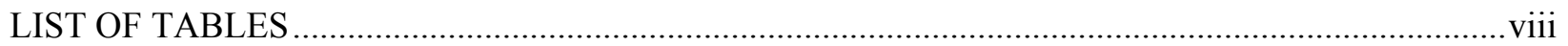

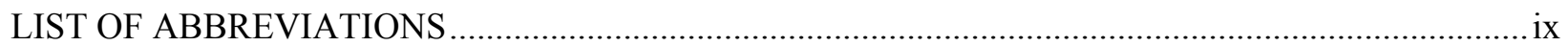

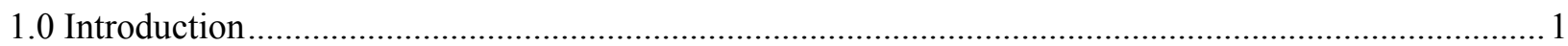

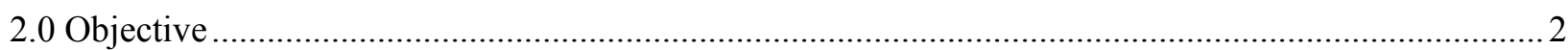

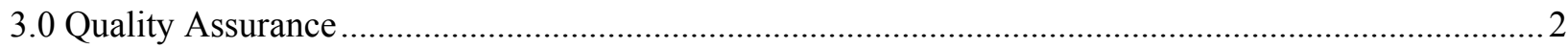

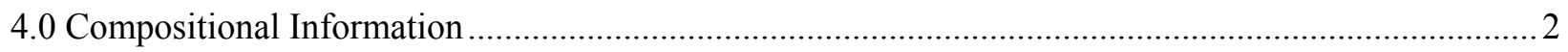

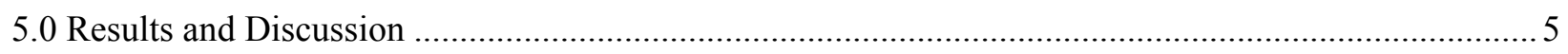

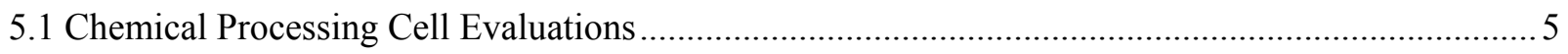

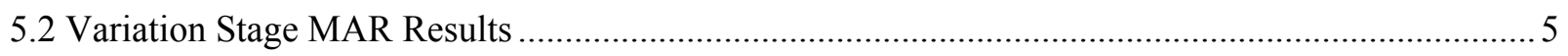

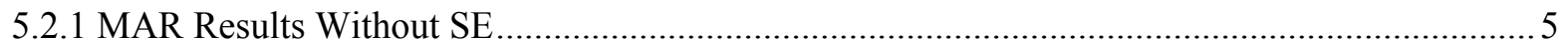

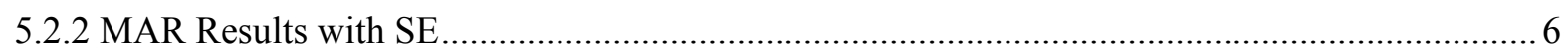

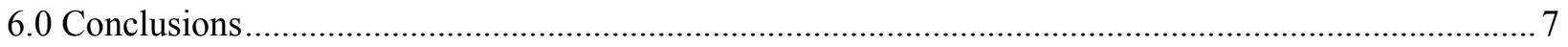

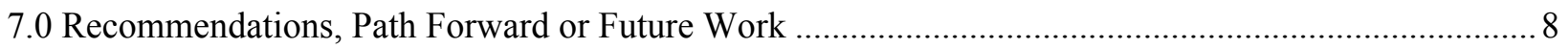

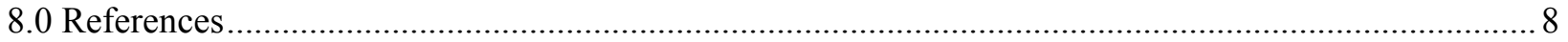




\section{LIST OF TABLES}

Table 4-1. SB8 Nominal Projections (Sludge-Only, 1000- and 2000-Gallons of ARP Added)..... 3

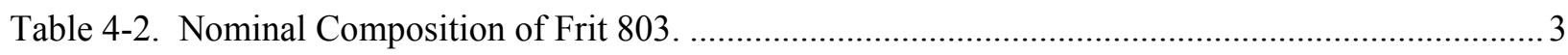

Table 4-3. Assumptions Used To Calculate the $\mathrm{Kg}$ of Boron Added to the SRAT................................... 4

Table 4-4. Concentration of $\mathrm{B}_{2} \mathrm{O}_{3}$ Added to the SRAT as a Function of SE Volume Added..................... 4

Table 5-1. Projected Operating windows for the Frit 803 - SB8 ...................................................... 6

Table 5-2. Projected Operating windows for the Frit 803 - SB8 …................................................... 7 


\section{LIST OF ABBREVIATIONS}

$\begin{array}{ll}\text { ARP } & \text { Actinide Removal Process } \\ \text { CPC } & \text { Chemical Process Cell } \\ \text { DWPF } & \text { Defense Waste Processing Facility } \\ \text { EVs } & \text { Extreme Vertices } \\ \text { MAR } & \text { Measurement Acceptability Region } \\ \text { MCU } & \text { Modular Caustic Side Solvent Extraction Unit } \\ \text { NGS } & \text { Next Generation Solvent } \\ \text { PCCS } & \text { Product Composition Control System } \\ \text { PRFT } & \text { Precipitate Reactor Feed Tank } \\ \text { SB } & \text { Sludge Batch } \\ \text { SE } & \text { Strip Effluent } \\ \text { SRAT } & \text { Sludge Receipt and Adjustment Tank } \\ \text { SRNL } & \text { Savannah River National Laboratory } \\ \text { SRR } & \text { Savannah River Remediation } \\ \text { T } & \text { Liquidus Temperature } \\ \text { TTR } & \text { Technical Task Request } \\ \text { TTQAP } & \text { Task Technical and Quality Assurance Plan } \\ \eta & \text { Viscosity } \\ \text { WL } & \text { Waste Loading }\end{array}$




\subsection{Introduction}

The Actinide Removal Process (ARP)/Modular Caustic Side Solvent Extraction Unit (MCU) Life Extension includes activities required to support ARP/MCU extended operations to treat dissolved salt cake waste (i.e., remove actinides, strontium, and cesium) and deliver a lowactivity decontaminated salt solution waste stream to the Saltstone Processing Facility (SPF). The resulting cesium and actinide/strontium salt stream is processed in the Defense Waste Processing Facility (DWPF). As a part of the ARP/MCU Life Extension Project, a next generation solvent (NGS) and a new strip acid will be deployed. The strip acid will be changed from dilute nitric acid to dilute boric acid $(0.01 \mathrm{M})$. Because of these changes, experimental testing with the next generation solvent is required to determine the impact of these changes (if any) to Chemical Process Cell (CPC) activities, glass formulation strategies, and melter operations at the DWPF.

Bricker issued a Technical Task Request (TTR) to support the assessments of the impact of the next generation solvent on the downstream DWPF flowsheet unit operations (i.e., CPC, glass formulation, and melter operations). ${ }^{1}$ Newell and Peeler issued a Task Technical and Quality Assurance Plan (TTQAP) in response to the TTR which outlined the technical approach to be used to meet programmatic objectives. ${ }^{2}$

The downstream impacts of the boric acid strip effluent (SE) to the Chemical Process Cell (CPC) processing have been previously evaluated. No impacts were noted for the CPC processing using boric acid on hydrogen generation, rheological properties, metal solubilities, foaming, or other processing parameters. The downstream impact of the boric acid SE on glass formulation activities and melter operations using the baseline flowsheet $(0.01 \mathrm{M}$ or $10 \mathrm{mM}$ boric acid concentration) have also previously been evaluated. ${ }^{3}$ The results of that paper study assessment indicated that Frit 418 was robust to the implementation of the baseline $0.01 \mathrm{M}$ boric acid SE into the Sludge Batch 7b (SB7b) flowsheet (sludge-only or ARP-added) ${ }^{\mathrm{a}}$. More specifically, the projected operating windows for the nominal SB7b projections remained essentially constant (i.e., $25-43$ or $25-44 \%$ waste loading (WL)) regardless of the flowsheet options (sludge-only, ARP added, and/or the presence of the SE). These results indicated that even if SE is not transferred to the Sludge Receipt and Adjustment Tank (SRAT), there would be no need to add boric acid (from a trim tank) to compositionally compensate for the absence of the boric acid SE in either a sludge-only or ARP-added SB7b flowsheet.

Since that assessment, the specifications of the incoming boric acid have been proposed (or defined) as $0.01 \mathrm{M} \pm 0.0025 \mathrm{M}$. In addition, DWPF has completed processing of SB7b and is currently processing Sludge Batch 8 (SB8). Therefore, a second request has been made for SRNL to assess the impact of imposing the boric acid molarity specifications on the SB8 flowsheet. $^{\text {b }}$ It should be noted that Peeler and Edwards recommended Frit 803 for SB8 processing and thus its composition will be used to support this assessment. ${ }^{4}$ The compositional bases for this assessment (sludge, ARP, and frit) will be discussed in detail in Section 4.0.

\footnotetext{
${ }^{\text {a }}$ In the 2011 assessment, introduction of the Actinide Removal Process (ARP) stream was based on Appendix J from S.G. Subosits, "Actinide Removal Process Material Balance Calculation with Low Curie Salt Feed," X-CLC-S-00113 Rev 0, Appendix J, September 24, 2004. To support the current assessment, the measured composition reported by DWPF of the Precipitate Reactor Feed Tank (PRFT) was used.

${ }^{\mathrm{b}}$ Personal communication from A. Samadi to D. Peeler, June 6, 2013 via email.
} 
As outlined in the TTQAP, the introduction of the dilute $(0.01 \mathrm{M})$ boric acid stream into the DWPF flowsheet has a potential impact on glass formulation and frit development efforts since $\mathrm{B}_{2} \mathrm{O}_{3}$ is a major oxide in frits developed for DWPF. Introduction of the boric acid in an upstream unit operation may require compositional adjustments to the frit to ensure both process and product performance properties are maintained during production. Given Frit 803 has already been recommended and procured for SB8 processing, the option of altering the frit to account for the incoming boron from the SE is not a preferred option. However, the response of Frit 803 to the introduction of the baseline SE including its compositional tolerances (i.e., up to $0.0125 \mathrm{M}$ boric acid) is of interest and the focus of this study. Therefore, the primary question to be addressed in the current study for impact of the boric acid on glass formulation and melter processing is: What is the impact (if any) on the projected operating windows for the Frit 803 SB8 flowsheet to additions of $\mathrm{B}_{2} \mathrm{O}_{3}$ from the SE in the SRAT? More specifically, will Frit 803 be robust to the potential compositional changes occurring in the SRAT due to sludge variation, varying additions of ARP and/or the introduction of SE by providing access to waste loadings of interest to DWPF? For the CPC evaluation, the primary question is whether the previous testing remains valid at the revised boric acid concentration.

To assess the impact of the introduction of the new SE on SB8 Slurry Mix Evaporator (SME) acceptability decisions, Variation Stage Measurement Acceptability Region (MAR) assessments developed by SRNL will be used. ${ }^{5}$

\subsection{Objective}

The objective of this report is to provide supplemental information on the downstream impacts of the new SE $(0.01 \mathrm{M}$ boric acid) on the projected operating windows for the Frit $803-\mathrm{SB} 8$ flowsheet given implementation of the new SE $(0.0125 \mathrm{M}$ accounting for the proposed compositional specifications or tolerances). Peeler and Edwards provided an initial assessment on the impact of the $0.01 \mathrm{M}$ boric acid flowsheet. ${ }^{3}$ Newell, et al., addressed the impacts to the CPC processing. ${ }^{6}$

\subsection{Quality Assurance}

Requirements for performing reviews of technical reports and the extent of review are established in manual E7 2.60. SRNL documents the extent and type of review using the SRNL Technical Report Design Checklist contained in WSRC-IM-2002-00011, Rev. 2.

\subsection{Compositional Information}

Given the introduction of the new SE is anticipated to occur during SB8 processing, the latest projections of SB8 were used to support this assessment. Table 4-1 summarizes the SB8 projection (sludge-only) from Savannah River Remediation (SRR) received on April 30, 2013. ${ }^{\text {a }}$ Table 4-1 also shows the addition of the ARP stream at two volumes (1000 and 2000 gallons) to

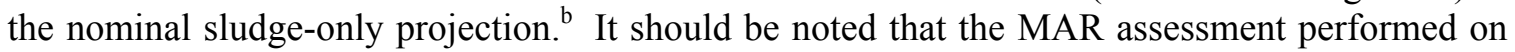
the coupled operations flowsheet used increments of 250 gallons of ARP product addition from 0 to 2000 gallons. Only the 1000 and 2000 gallons projections are shown in Table 4-1. As

\footnotetext{
${ }^{\text {a }}$ SB8 projections were received via email from D.W. McIlmoyle to D.K. Peeler on 4-30-13 (see SRNL-NB-201200070, page 123 for more details).

${ }^{\mathrm{b}}$ Nominal coupled operations projections are based on the measured PRFT materials as reported by DWPF.
} 
previously mentioned, Peeler and Edwards recommended Frit 803, whose nominal composition is provided in Table 4-2, for processing SB8. ${ }^{4}$

Table 4-1. SB8 Nominal Projections (Sludge-Only, 1000- and 2000-Gallons of ARP Added) (wt \%, calcined oxides).

\begin{tabular}{|c|c|c|c|}
\hline $\begin{array}{l}\text { Sludge } \\
\text { ID }\end{array}$ & $\begin{array}{c}\text { SB8 } \\
\text { Sludge-Only }\end{array}$ & $\begin{array}{l}\text { SB8 } 1000 \text { Gallons } \\
\text { of ARP }\end{array}$ & $\begin{array}{c}\text { SB8 } 2000 \text { Gallons } \\
\text { of ARP }\end{array}$ \\
\hline $\mathrm{Al}_{2} \mathrm{O}_{3}$ & 17.923 & 16.901 & 16.009 \\
\hline BaO & 0.129 & 0.120 & 0.112 \\
\hline $\mathrm{CaO}$ & 2.003 & 1.874 & 1.761 \\
\hline $\mathrm{Ce}_{2} \mathrm{O}_{3}$ & 0.337 & 0.315 & 0.295 \\
\hline $\mathrm{Cr}_{2} \mathrm{O}_{3}$ & 0.152 & 0.147 & 0.144 \\
\hline $\mathrm{CuO}$ & 0.056 & 0.054 & 0.051 \\
\hline $\mathrm{Fe}_{2} \mathrm{O}_{3}$ & 31.575 & 29.464 & 27.621 \\
\hline $\mathrm{K}_{2} \mathrm{O}$ & 0.136 & 0.194 & 0.244 \\
\hline $\mathrm{La}_{2} \mathrm{O}_{3}$ & 0.082 & 0.076 & 0.071 \\
\hline MgO & 0.510 & 0.477 & 0.448 \\
\hline MnO & 9.247 & 8.621 & 8.075 \\
\hline $\mathrm{Na}_{2} \mathrm{O}$ & 23.374 & 25.943 & 28.185 \\
\hline $\mathrm{NiO}$ & 2.769 & 2.583 & 2.421 \\
\hline PbO & 0.046 & 0.043 & 0.040 \\
\hline $\mathrm{SO}_{4}$ & 1.629 & 1.629 & 1.629 \\
\hline $\mathrm{SiO}_{2}$ & 2.905 & 2.814 & 2.735 \\
\hline $\mathrm{ThO}_{2}$ & 1.276 & 1.189 & 1.113 \\
\hline $\mathrm{TiO}_{2}$ & 0.033 & 2.107 & 3.918 \\
\hline $\mathbf{U}_{3} \mathbf{O}_{8}$ & 5.591 & 5.234 & 4.923 \\
\hline $\mathrm{ZnO}$ & 0.053 & 0.050 & 0.046 \\
\hline $\mathrm{ZrO}_{2}$ & 0.175 & 0.167 & 0.159 \\
\hline
\end{tabular}

Table 4-2. Nominal Composition of Frit 803.

\begin{tabular}{|c|c|}
\hline Oxide & Frit $\mathbf{8 0 3}$ \\
\hline $\mathbf{B}_{\mathbf{2}} \mathbf{O}_{3}$ & 8 \\
\hline $\mathbf{L i}_{2} \mathbf{O}$ & 6 \\
\hline $\mathbf{N a}_{\mathbf{2}} \mathbf{O}$ & 8 \\
\hline $\mathrm{SiO}_{\mathbf{2}}$ & 78 \\
\hline
\end{tabular}


With respect to the contribution of boron oxide from the strip effluent, calculations were performed by SRNL for a $0.0125 \mathrm{M}$ boric acid $(0.01 \mathrm{M} \pm 0.0025 \mathrm{M}$ tolerance) upper bound as a function of the volume of SE added to the SRAT. The assumptions and inputs used by SRNL to perform these calculations are provided in Table 4-3 with the resulting output shown in Table 4-4.

Table 4-3. Assumptions Used To Calculate the Kg of Boron Added to the SRAT.

\begin{tabular}{|lcl|}
\hline Amount of SRAT product transferred per batch & 4,500 & Gallons from SRAT \\
\hline Amount of SRAT product transferred per batch & 17,033 & liters from SRAT \\
\hline SRAT Product Density & 1.25 & $\mathrm{~kg} / \mathrm{L}$ \\
\hline SRAT Nitric Acid Amount & 50 & $\mathrm{gallons}$ \\
\hline SRAT Formic Acid Amount & 350 & gallons \\
\hline Nitric Acid Concentration & 10 & Molar \\
\hline Formic Acid Concentration & 23.6 & Molar \\
\hline SRAT Product Calcine Solids & 0.15 & $\mathrm{~g}$ oxide/g sludge \\
\hline Waste Loading & 42 & $\%$ \\
\hline Frit Boron Oxide Concentration & 8 & $\mathrm{wt} \%$ \\
\hline Boron Oxide Molecular Weight & 69.62 & $\mathrm{~g} / \mathrm{mol}$ \\
\hline Boron Elemental Weight & 10.811 & $\mathrm{~g} / \mathrm{mol}$ \\
\hline Amount of SRAT product transferred per batch & 21,291 & $\mathrm{~kg}$ \\
\hline SRAT Nitric Acid Amount & 189 & Liters \\
\hline SRAT Formic Acid Amount & 1,325 & Liters \\
\hline SRAT Nitric Acid Amount & 1,893 & Moles \\
\hline SRAT Formic Acid Amount & 31,264 & Moles \\
\hline Total Acid Amount & 33,157 & Moles \\
\hline Amount of SRAT product oxides & 3,194 & $\mathrm{~kg}$ sludge oxide \\
\hline Amount of Glass Produced & 7,604 & $\mathrm{~kg}$ glass \\
\hline
\end{tabular}

Table 4-4. Concentration of $\mathrm{B}_{2} \mathrm{O}_{3}$ Added to the SRAT as a Function of SE Volume Added.

\begin{tabular}{llccccl|} 
Strip Effluent Impacts & $\mathbf{0 . 0 1 2 5}$ M Boric Acid & & \\
& & & & & \\
\hline Strip Effluent Added per SRAT Batch & 5,000 & 20,000 & 50,000 & 70,000 & liters \\
\hline Strip Effluent Added per SRAT Batch & 1321 & 5284 & 13210 & 18494 & gallons \\
\hline Amount of Boron in Strip Effluent & 62.5 & 250 & 625 & 875 & moles \\
\hline Amount of Boron in Strip Effluent & 0.7 & 2.7 & 6.8 & 9.5 & $\mathrm{~kg}$ \\
\hline Percentage of Acid Added to SRAT in SE & 0.6 & 2.3 & 5.7 & 7.9 & $\%$ \\
\hline Amount of Boron Oxide per SRAT Batch & 2.2 & 8.7 & 21.8 & 30.5 & $\mathrm{~kg}$ \\
\hline $\begin{array}{l}\text { Concentration of Boron Oxide in SRAT Product Calcined } \\
\text { Solids }\end{array}$ & 0.07 & 0.27 & 0.68 & 0.95 & $\mathrm{wt} \%$ \\
\hline
\end{tabular}

Using a bounding 70,000 liters of SE added per SRAT batch and assuming a $0.0125 \mathrm{M}$ (or $12.5 \mathrm{mM}$ ) SE boric acid concentration, $9.5 \mathrm{~kg}$ of boron (elemental) (or $30.5 \mathrm{~kg}$ of $\mathrm{B}_{2} \mathrm{O}_{3}$ on a calcined oxide basis) would be added to the SRAT. Therefore, the total mass of sludge oxides in the SRAT including the $\mathrm{B}_{2} \mathrm{O}_{3}$ contribution would increase to $3224.5 \mathrm{~kg}$ of calcined sludge oxides (3194 kg of sludge oxides $+30.5 \mathrm{~kg}$ of $\mathrm{B}_{2} \mathrm{O}_{3}$ from SE). The percent of boron in the SRAT can 
then be calculated as $(30.5 \div 3224.5) * 100$ which yields $0.95 \mathrm{wt} \%$ (calcined solids) of $\mathrm{B}_{2} \mathrm{O}_{3}$ in the SRAT.

In the previous assessment, ${ }^{3}$ the $\mathrm{B}_{2} \mathrm{O}_{3}$ contribution was calculated to be $0.84 \mathrm{wt} \%$ for the nominal baseline flowsheet of $0.01 \mathrm{M}$ boric acid. It should be noted that the use of 70,000 liters of SE per SRAT could be considered a bounding case given current limitations of approximately 55,000 liters (or 15,000 gallons) to the SRAT. For example, if DWPF were to operate using 20,000 liters of SE per SRAT batch, then the $\mathrm{B}_{2} \mathrm{O}_{3}$ contribution to the SRAT would be $0.27 \mathrm{wt} \%$ - a factor of $\sim 3 \mathrm{X}$ lower than that being carried forward in the assessment.

\subsection{Results and Discussion}

\subsection{Chemical Processing Cell Evaluations}

A review was conducted of the previous testing to determine if the change from a $0.010 \mathrm{M}$ boric acid concentration in the strip effluent to a $0.0125 \mathrm{M}$ concentration would have a noticeable impact on the CPC process. A review of the acid calculations from the test runs indicated that boric acid accounted for approximately $5 \%$ of the total acid added during the testing. A change from 0.010 to $0.0125 \mathrm{M}$ for the boric acid concentration reflects a $25 \%$ change in the amount of boric acid, but only a $1.3 \%$ change in the acid added during the tests. A change in acid concentration of this magnitude is insufficient to alter the outcome of the testing given the amount of uncertainty in the acid calculation. The previous test results are not invalidated by the change in boric acid concentration and additional testing or evaluations are not considered necessary to conclude that the boric acid will not impact CPC processing.

\subsection{Variation Stage MAR Results}

\subsubsection{MAR Results Without SE}

A Variation Stage assessment of the sludge projections of Table 4-1 (without boric acid) hasbeen reported previously. ${ }^{\text {a }}$ That Variation Stage MAR assessment was following the same approach as described by Peeler and Edwards. ${ }^{5}$ Specifically, the standard variation approach was applied to each column of sludge projections in Table 4-1 (i.e., $\pm 7.5 \%$ around the major oxides, and \pm 0.5 $\mathrm{wt} \%$ around the minor oxides). These sludge composition intervals were then used to generate extreme vertices (EVs) for each of the sludge projections of Table 4-1. The EVs were then coupled with Frit 803 over a WL interval of $25-50 \%$ WL to determine the WL interval over which all of the EVs were classified as acceptable for both process and product performance constraints as defined by DWPF's Product composition Control System (PCCS).

Table 5-1 summarizes the results of the MAR assessments for the Frit 803 - SB8 system with and without ARP (SE was not accounted for in this previous assessment).

\footnotetext{
${ }^{\text {a }}$ The results of the Variation Stage assessment (i.e., projected operating windows) were transmitted to SRR on 5-1-13 via personal communication (email) - see page 124 of SRNL-NB-2012-00070 for more details.
} 


\section{Table 5-1. Projected Operating windows for the Frit 803 - SB8 Sludge Only and Coupled Operations Systems (No Strip Effluent Added)}

\begin{tabular}{|ccc|}
\hline $\begin{array}{c}\text { Sludge/ARP } \\
\text { (gallons) }\end{array}$ & $\begin{array}{c}\text { Projected Operating } \\
\text { Window }\end{array}$ & $\begin{array}{c}\text { \# of EVs failed at } \\
\text { next highest WL }\end{array}$ \\
\hline $\mathbf{0}$ & $30-40\left(\mathrm{~T}_{\mathrm{L}}\right)$ & 14 out of 4202 \\
\hline $\mathbf{1 0 0 0}$ & $28-43($ low $\eta)$ & 165 out of 4440 \\
\hline $\mathbf{1 2 5 0}$ & $27-42($ low $\eta)$ & 12 out of 4440 \\
\hline $\mathbf{1 5 0 0}$ & $27-42($ low $\eta)$ & 150 out of 4440 \\
\hline $\mathbf{1 7 5 0}$ & $26-42($ low $\eta)$ & 297 out of 4440 \\
\hline $\mathbf{2 0 0 0}$ & $29-41($ low $\eta)$ & 113 out of 4440 \\
\hline
\end{tabular}

The Frit 803 - SB8 sludge-only operating window is $30-40 \%$ WL with predictions of liquidus temperature $\left(\mathrm{T}_{\mathrm{L}}\right)$ limiting access to higher WLs. At $41 \% \mathrm{WL}$ for the sludge-only flowsheet, 14 out of the $4202 \mathrm{EVs}$ fail $\mathrm{T}_{\mathrm{L}}$. As the ARP product is added to the SRAT, the projected operating windows initially increase (up to 1000 gallons of ARP product) to $28-43 \% \mathrm{WL}$ and transition from a $\mathrm{T}_{\mathrm{L}}$ limited system to a low viscosity (low $\eta$ ) limited system due to the additional $\mathrm{Na}_{2} \mathrm{O}$ being added to the glass from ARP coupled with higher targeted WLs. With the addition of 1250 gallons of ARP product, the maximum WL that can be attained is reduced to $42 \%$ given the continual increase in $\mathrm{Na}_{2} \mathrm{O}$ content which drives viscosity predictions to lower values and thus cuts off access to higher WLs. At $43 \%$ WL, 12 out of the 4440 EVs fail low $\eta$. A gradual reduction (albeit it slight and still very acceptable) in the upper WL that can be achieved continues with ARP additions up to 2000 gallons. ARP product additions greater than 2000 gallons were not assessed given the known impact of $\mathrm{TiO}_{2}$ concentration on the projected operating window. That is, with ARP product additions greater than 2000 gallons, the $\mathrm{TiO}_{2}$ content in the glass at $40 \% \mathrm{WL}$ exceeds the $2 \mathrm{wt} \% \mathrm{TiO}_{2}$ (in glass) PCCS limit. Hence the current restrictions placed on the amount of ARP product that can be added to the SRAT until the $\mathrm{TiO}_{2}$ solubility limit and the $T_{L}$ model are revised.

The results of this assessment indicate that Frit 803 is a viable option for the 4-30-13 SB8 projection (with variation applied) for both sludge-only and coupled operations up to 2000 gallons of ARP. Viable in this context means that the projected operating windows range from at least as low as $32 \% \mathrm{WL}$ to as least as high as $40 \% \mathrm{WL}$ with sludge variation accounted for. This projected window will allow DWPF to target a nominal $36 \% \mathrm{WL}$ and provide some robustness to WL variation ( $\pm 4 \mathrm{WL}$ points) that has been observed during normal facility operations.

\subsubsection{MAR Results with SE}

So given this baseline, what is the impact of the addition of 70,000 liters of SE to the SRAT on the projected operating windows? As previously mentioned, the 70,000 liters of SE translates into $0.95 \mathrm{wt} \% \mathrm{~B}_{2} \mathrm{O}_{3}$ in the SRAT. An enhanced Variation Stage assessment was performed as part of this study in which the EVs of the sludge components were based on the minimum and maximum values of the 4-30-13 projection and, to account for the $\mathrm{SE}$ addition, a $\mathrm{B}_{2} \mathrm{O}_{3}$ component was added with a range of 0 to $2 \mathrm{wt} \%$. The use of $2 \mathrm{wt} \%$ is almost twice the oxide content of the $0.95 \mathrm{wt} \%$ calculated based on the assumptions and inputs shown previously. It should be noted that the $\mathrm{B}_{2} \mathrm{O}_{3}$ range of $0-2 \mathrm{wt} \%$ is larger than applying either a $\pm 7.5 \%$ or a $\pm 0.5 \mathrm{wt} \%$ value around the nominal $0.94 \mathrm{wt} \%$. 
The results of the SE-based Variation Stage assessment are shown in Table 5-2. A comparison of Table 5-1 and Table 5-2 shows very little difference in the projected operating windows with and without SE added to the SRAT. The sludge-only flowsheet (no ARP) yields the identical projected operating window of $30-40 \% \mathrm{WL}$. The same general trends are observed with the SEbased coupled operations flowsheet as shown in Table 5-1. With initial additions of ARP and accounting for SE (up to $2 \mathrm{wt} \%$ ), the projected operating windows increase to $28-43 \% \mathrm{WL}$ and transition to a low $\eta$ limited system. With further additions of ARP (while still accounted for 2 $w t \% \mathrm{SE}$ ), the upper achievable WL gradually decreases due to the additional $\mathrm{Na}_{2} \mathrm{O}$ being added to a low $\eta$ system. The two differences observed between Table 5-1 and Table 5-2 are the upper WL for the 1750 gallon addition of ARP (41 and 42\% WL with and without SE accounted for, respectively) and the dual constraint limitation with 2000 gallons of ARP added for the SE-based assessments. More specifically, both low $\eta$ and durability $\left(\Delta \mathrm{G}_{\mathrm{P}}\right)$ limit access to WLs of $42 \%$ and higher for the SE-based coupled operations flowsheet.

These results indicate that the $0.0125 \mathrm{M}$ (or $12.5 \mathrm{mM}$ ) boric acid upper limit (based on anticipated compositional tolerances) will have very little, if any, impact on the projected operating windows for the Frit 803 - SB8 system regardless of the presence or absence of ARP and SE.

Table 5-2. Projected Operating windows for the Frit 803 - SB8 Sludge Only and Coupled Operations (ARP and SE) Systems (Strip Effluent Added - 0 to 2 wt\%)

\begin{tabular}{|c|cc|}
$\begin{array}{c}\text { Sludge/ARP/SE } \\
\text { (gallons) }\end{array}$ & $\begin{array}{c}\text { Projected Operating } \\
\text { Window }\end{array}$ & $\begin{array}{c}\text { \# of EVs failed at } \\
\text { next highest WL }\end{array}$ \\
\hline $\mathbf{0}$ & $30-40\left(\mathrm{~T}_{\mathrm{L}}\right)$ & 14 out of 8806 \\
\hline $\mathbf{1 0 0 0}$ & $28-43($ low $\eta)$ & 279 out of 9179 \\
\hline $\mathbf{1 2 5 0}$ & $27-42($ low $\eta)$ & 37 out of 9221 \\
\hline $\mathbf{1 5 0 0}$ & $27-42($ low $\eta)$ & 237 out of 9221 \\
\hline $\mathbf{1 7 5 0}$ & $26-41($ low $\eta)$ & 5 out of 9221 \\
\hline $\mathbf{2 0 0 0}$ & $29-41\left(\right.$ low $\left.\eta / \Delta \mathrm{G}_{\mathrm{P}}\right)$ & 195 out of 9221 \\
\hline
\end{tabular}

\subsection{Conclusions}

The introduction of the dilute $(0.01 \mathrm{M})$ boric acid stream into the DWPF flowsheet has potential impact on glass formulation and frit development efforts since $\mathrm{B}_{2} \mathrm{O}_{3}$ is a major oxide in frits developed for DWPF. Prior knowledge of this stream can be accounted for during frit development efforts but that was not the case for SB8. Frit 803 has already been recommended and procured for SB8 processing; altering the frit to account for the incoming boron from the SE is not an option. Therefore, the response of Frit 803 to the introduction of the baseline SE including its compositional tolerances (i.e., up to $0.0125 \mathrm{M}$ boric acid) is of interest and was the focus of this study. The primary question to be addressed in the current study was: What is the impact (if any) on the projected operating windows for the Frit 803 - SB8 flowsheet to additions of $\mathrm{B}_{2} \mathrm{O}_{3}$ from the SE in the SRAT? More specifically, will Frit 803 be robust to the potential compositional changes occurring in the SRAT due to sludge variation, varying additions of ARP and/or the introduction of SE by providing access to waste loadings (WLs) of interest to DWPF? 
To support this assessment, SRNL performed Variation Stage MAR assessments for Frit 803 SB8 potential flowsheets involving sludge-only and coupled (with and without ARP and SE) operations. The metric to gage the impact of the addition of SE was based on the projected operating windows which are defined as the WL interval over which glasses are classified as acceptable based on current DWPF PCCS models. Calculations were made based on an assumed 70,000 liters of SE added to the SRAT which translated into $30.5 \mathrm{~kg}$ of $\mathrm{B}_{2} \mathrm{O}_{3}$ (calcined oxide basis) being added to the SRAT or ultimately $0.95 \mathrm{wt} \% \mathrm{~B}_{2} \mathrm{O}_{3}$ in the calcined SRAT product. Although the volumes used to support this calculation are considered bounding, SRNL utilized a maximum $\mathrm{B}_{2} \mathrm{O}_{3}$ content of $2 \mathrm{wt} \%$ in the SRAT to support this assessment (i.e., a 2x increase).

These MAR results indicate that there is very little, if any, impact on the projected operating windows for the Frit 803 - SB8 system regardless of the presence or absence of ARP (up to 2000 gallons) and $\mathrm{SE}$ (up to $2 \mathrm{wt} \% \mathrm{~B}_{2} \mathrm{O}_{3}$ contained in the SRAT).

The impact on CPC processing of a $0.01 \mathrm{M}$ boric acid solution for elution of cesium during Modular Caustic Side Solvent Extraction Unit (MCU) processing has previously been evaluated by the Savannah River National Laboratory (SRNL). Increasing the acid strength to $0.0125 \mathrm{M}$ boric acid to account for variations in the boric acid strength has been reviewed versus the previous evaluation. The amount of acid from the boric acid represented approximately $5 \%$ of the total acid during the previous evaluation. An increase from 0.01 to $0.0125 \mathrm{M}$ boric acid represents a change of approximately $1.3 \%$ which is well within the error of the acid calculation. Therefore, no significant changes to CPC processing (hydrogen generation, metal solubilities, rheological properties, REDOX control, etc.) are expected from an increase in allowable boric acid concentration from $0.01 \mathrm{M}$ to $0.0125 \mathrm{M}$.

\subsection{Recommendations, Path Forward or Future Work}

The following recommendation is made based on the results of this study:

$>$ If the molarity of the boric acid flowsheet is increased above that corresponding to $2 \mathrm{wt} \%$ $\mathrm{B}_{2} \mathrm{O}_{3}$ in the SRAT (on a calcined oxide basis), the ramifications on predicted properties and SME acceptability decisions could become more serious warranting additional evaluations.

\subsection{References}

1. J.M. Bricker, "Testing for ARP/MCU Life Extension Project - DWPF," Savannah River Remediation, Aiken, South Carolina, HLW-DWPF-TTR-2010-0045, December 2010.

2. J.D. Newell and D.K. Peeler, "Task Technical and Quality Assurance Plan for Evaluation of DWPF Impacts of Boric Acid Use in Desium Strip for SWPF and MCU," Savannah River National Laboratory, Aiken, South Carolina, SRNL-RP-2010-01732, January 2011.

3. D.K. Peeler and T.B. Edwards, "The Impact of the MCU Life Extension Solvent on DWPF Glass Formulation Efforts," Savannah River National Laboratory, Aiken, South Carolina, SRNL-STI-2011-00110, March 2011.

4. D.K. Peeler and T.B. Edwards, "Frit Recommendation for Sludge Batch 8," Savannah River National Laboratory, Aiken, South Carolina, SRNL-L3100-2012-00195, June 2013. 
5. D.K. Peeler and T.B. Edwards, "Frit Development Effort for SB4: Nominal and Variation Stage Assessments," Westinghouse Savannah River Company, Aiken, SC, WSRC-TR2005-00372, Revision 0, 2005.

6. J.D. Newell, D. K. Peeler, T.B. Edwards, M.S. Hay, M. E. Stone, "DWPF Flowsheet Studies with Simulant to Determine the Impact of Next Generation Solvent on the CPC Process and Glass Formulation, Savannah River National Laboratory, Aiken, SC, SRNLSTI-2011-00273, Revision 0, 2011. 


\section{Distribution:}

S. L. Marra, 773-A

T. B. Brown, 773-A

D. R. Click, 999-W

S. D. Fink, 773-A

C. C. Herman, 773-A

E. N. Hoffman, 999-W

F. M. Pennebaker, 773-42A

W. R. Wilmarth, 773-A

D. K. Peeler, 999-W

T. B. Edwards, 999-W

M. E. Stone, 999-W

J. D. Newell, 999-W

D. P. Lambert, 999-W

H.P. Boyd, 704-27S

J. M. Bricker, 704-27S

T. L. Fellinger, 704-26S

E. J. Freed, 704-S

J. M. Gillam, 766-H

B. A. Hamm, 766-H

E. W. Holtzscheiter, 704-15S

J. F. Iaukea, 704-27S

D. W. McImoyle, 766-H

J. W. Ray, 704-S

P. J. Ryan, 704-30S

A. Samadi, 704-27S

H. B. Shah, 766-H

D. C. Sherburne, 704-S

A. R. Shafer, 704-27S

R. H. Spires, 248-8H

S.C. Tester, 704-27S

Records Administration (EDWS) 